\title{
ISLAM AND CIVILIZATION
}

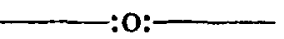

WITHout discussing the effect of modern civilized life on religious thought in general, I propose to show that civilization and Islam do not blend well, and that where the attempt has been made it has been to the detriment of both.

Commence with the birth of that great movement, and contrast Medina's frugality and zeal with the later luxury of Baghdad tottering to her fall. How came it that the force which grew a Bedouin crop of armed devotees to fight and die with eager confidence, and dictate a policy and creed to influence a hemisphere, could not guard the very centre of its being from the thrust of an alien host? The historian, the missionary and the savant have each an answer to this question. $\dot{I}$, who only claim to be an observer of modern Arabians and kindred races under civilization and barbarism, maintain that Islam,-like some mountain herb from upland slopes,-becomes rank, coarse, and finally atrophied in the hothouse of civilization. Its founder intended it to meet the special and every-day needs of a semi-nomadic race living in a more or less barren region, under arduous conditions. Being only human, he could not be expected to think accurately outside the only environment he knew, and beyond the limits of his time. Therefore, when the phenomenal spread of Islam as a world power gave birth to a collateral civilization, the Prophet's successors and their advisers had to formulate a scheme to regulate the relations between civilized life and their original faith. Eventually the parasitic growth of civilization choked or poisoned the parent plant, and this, I maintain, has been 
the case wherever and whenever the experiment has been tried. History is full of such examples, which may also be observed in civilized Moslem states to-day.

The curse is double-edged and cuts both ways: Islam degenerates under civilized conditions, and civilization becomes slack and inert in conjunction with Islam, within the four corners of which all Moslem art and science and literature has to keep.

Take Cairo, for example,-the centre of Islamic learning, and a vast city that has experienced a century of European civilization. Ask any conscientious Moslem if the general state of Islam in Cairo is worthy of its original traditions; then ask yourself if you would care to show Cairo to an intelligent barbarian as an example of the benefits of civilization. He might marvel at the motor-cars, trams, electric light, fine streets and shops; but if he were really intelligent, he would ask more of civilization than that it increase human wants and supply them in proportion to the wealth of the individual or even of the community. He would peep into slums and mean streets, note Cairene pleasures and their parasites, and decide that civilization had here failed to make good.

Other instances could be given of Moslem cities administered entirely by Moslems, which would furnish still more striking examples of civilization's failure ; but, in the interests of accurate comparison, I prefer to illustrate my argument with cases culled from one race and one region-Arabia Felix, where Islamic civilization, with a thin veneer of European refinement, may be observed side by side with the old patriarchal system on which Islam was based. I also claim some fourteen years experience of these people, in health and sickness, poverty and plenty, peace and war. I have fought with them and against them; have seen them flushed with victory and known them sadly defeated; I have lived among them as one of themselves, and met their chiefs in durbar as a representative of the British Government. There is no occasion to mention specific cases, nor would the average reader be much wiser if names were given. 'Typical examples will suffice to illustrate my argument. 
Take any sultanate on the littoral plain north of the Gulf of Aden and in touch with that port and other seaports of the East; then crossing the great barrier range of hills, select any inland tribal administration that is homogeneous and large enough to form a suitable parallel. Small semi-detached clans of hillsmen need not be considered. They owe allegiance to some sultan and profess Islam, but no one is rash enough to interfere with their affairs except under compulsion, and their own co-religionists frankly doubt the existence of religious thought among them. They boast of pre-Islamic origin and pre-Islamic ways : both claims are justified.

In our maritime sultanate we shall find a people whom intercourse with Europeans and civilized marts has rendered fairly intelligent from a modern commercial point of view, while the might of Aden has made them tractable and law-abiding within certain limits. They will not lightly slay, for years of peace have taught them to value human life; nor will they indulge in unprovoked raids, nor harry adjacent borders as a pastime. They have learned that such episodes attract speedy retribution, or at least inevitable and embarrassing enquiries.

In our inland state, on the other hand, no high value is set on human life beyond the wholesome restraint of the blood feud, and alien strength is scoffed at, for no Power would care to launch a column far up among those towering hills into a country whose roads are mere camel-tracks and whose food and water supply would not suffice an adequate force. Extraneous influence is, therefore, at a discount, and the up-country potentate need not cast side glances at Aden or conform to civilized procedure.

The littoral sultan must so conform, outwardly at least, if he wishes to avoid trouble with the protecting Power. His rule may be described as that of a benevolent despot, whose benevolence varies in direct proportion to the accessibility of his capital from Aden, or the benefits he receives or hopes to receive therefrom. He is despotic because his sway is not influenced by the opinion of his subjects. These are divided, as in all South Arabian sultanates, into two broad classes, the raya, or civilians 
who pay taxes and are exempt from military service, and the kubail, or tribesmen who pay no taxes, give military service when called upon, and elect their own chiefs from members of a ruling house. Such chiefs should confer with the sultan on matters of state touching the honour or welfare of the tribe, for under purely tribal conditions they control the armed strength of the sultanate. Here our maritime ruler scores, for he is usually a man of wealth, thanks to his transit dues and a large tax-paying population. Wealth means power here, as elsewhere, and if the sultan has some pet scheme of conquest, coercion or reprisal which his tribal chiefs will not support, he hires levies from the more warlike hill tribes to work his will, and sends to the dominant Power at Aden an artfully worded explanation, if he considers it necessary. This is politely accepted at its face value, in the absence of further information. Thus the littoral ruler need not bother about the Islamic code if he can retain the ear of authority at Aden, which he usually contrives to do.

The over-lord of a tribal state in the interior cannot afford to pay for levies to uphold his policy. His taxpaying population is comparatively small, and to tax a tribesman is like getting honey from wild bees-little honey and big trouble. Moreover, he dare not bring such levies within the limits of his sultanate to use against refractory vassals, though he may induce a vassal clan to punish another for a breach of tribal law. The tribes can and do depose a sultan at short notice for unconstitutional acts ; therefore it behoves an inland potentate to conform to tribal usage and procedure. The opinion of authority at Aden is nothing to him.

Let us contrast the state of Islam in each of these cases.

In the littoral sultanate the outward observance of Islam is much in evidence. Mosques are frequent and well endowed, private devotions are unimpeded by hazardous surroundings ; and, let me add, the necessary ablutions are more agreeable in the hot climate of the maritime plain than in the cold, keen air of the uplands. Lowlanders are, therefore, more instant in prayer than up-country folk. But when it comes to rigorous fasting 
on the march or steady courage and resignation in the hour of pain and death, which is what Islam really means or should mean,- then the maritime plainsman shows at a disadvantage. He lives in ease; he has a brisk carrying trade close to busy caravan routes, and is seldom called out to fight by his liege, for fighting is expensive and may draw awkward questions from the suzerain Power. Consequently, when he meets the mountaineer in battle, or even the less civilized outlaw of the maritime plain, he fails to give a good account of himself, in spite of the fact that he is usually better armed and equipped than his hardy foe. He cannot stand the stress of wilderness warfare in a shadeless region beneath a tropic sun; his foe, with less provisions and water, is a better stayer and far more nimble on his feet.

Though lax in his religious observances, the uncivilized tribal warrior holds the root and essence of Islam-resignation to God's will and indifference to earthly ills. An hereditary fighter, he lives and dies hard, and is sure of himself and his destiny.

The civilized Moslem has learned enough to know that there are two sides to every question. Islam does promise rewards in the hereafter, but it also threatens. How is the to know for certain whether he is due for reward or punishment, It is all very well for him to say that as a Moslem he is the heir of eternal bliss, but his life is far more complex than that of his barbaric compatriot; and when he hears the long-drawn yell of a tribal advance, he is not quite so sure of the hereafter as he was when loafing about the bazaars of his market town. May he not have sinned grievously in the course of his daily life, in close contact with the works of unbelievers ? And the work he is now engaged in has no personal aspect for him. He is there merely because his clan had to send a draft of men at the sultan's bidding, and he happened to be chosen. His foe, on the other hand, came with intent to kill, and, if necessary, be killed. Hence it is that an imposing force may fare forth from the capital of some maritime sultanate, and find itself held ridiculously in check by a handful of agile sharpshooters. Nor is it merely the superior physical condition 
and courage engendered by a hardy life that gives the uncivilized Moslem his advantage. It is his sturdy faith as a Moslem that sees him through; without it he does not show to advantage.

This was brought home to me once among the beetling heights that culminate in the great main range of Southern Arabia. My party was crossing a lofty watershed some 7000 feet above sea level, the border line between two belligerent clans of the same tribe. The siyarah, or local escort, was drawn from the clan whose territory we were about to enter, their neighbours having refused us safe conduct. As a natural consequence, we were sniped persistently during our short journey through the latter's territory, and had to engage the snipers at long range in order to make them keep their distance and prevent casualties among our camels and drivers. As we scaled the pass that led out of the limits of that cantankerous clan, they became more importunate in their attentions, and we had to extend in the rear of our caravan and maintain a continuous fire to ensure its safe withdrawal. I noticed a certain amount of coyness among the local escort, an exaggerated sense of selfpreservation, so to speak, which was new to me and inconsistent with what $I$ knew of this clan as combatants. The firing was at long range and ill-directed, which made their attitude the more remarkable. After we had hurried the camels over the pass and exchanged a few valedictory shots with our opponents, I spoke to the sheikh in charge of the local escort tactfully, of course, merely mentioning that I had noticed some signs of trepidation among his men which the occasion had not seemed to justify and which was unworthy of their reputation. "They feared indeed," he replied, " not death, but the fire of hell, for we were fighting kith and kin. Jehannam is the portion of those who die in such a strife." I may add that this tribe is noted throughout Southern Arabia for daring raids outside its own limits.

A member of this same clan once belonged to my personal escort. It was related to me how he, armed with only a spear, once met a matchlock man with whose tribe the clan in question was at deadly feud. The matchlock 
man blew on the face of his weapon and summoned my henchman to surrender. The spearman stooped, snatched a stone, and hurled it with force and precision, knocking the matchlock aside just as the answering shot cracked forth. My follower then ran in and slew his man. He attached little importance to the incident itself, but was particularly anxious to impress upon me that he had bought a quantity of white cotton fabric wherewith to make a decent shroud and had arranged for the burial himself, as the man had been slain outside the limits of his own tribe, and the feud prevented his relatives from claiming the body.

Such is the mettle of Islam when tempered by hardship and a simple, strenuous life. Once import civilization and the Moslem character is sapped thereby. Nigeria, the Sudan and similar provinces owe their physical and moral welfare to the fact that a parental government is wise and strong enough to confer such benefits of civilization as seem most suited to their needs, and withhold its drawbacks.

The attilude of the South Arabian tribesman toward civilization is shrewd enough. He will buy, beg, borrow or steal a breech-loading firearm at any cost, whatever difficulties are put in his way by a far-sighted government. $\mathrm{He}$ is also a regular buyer of such necessities as matches, kerosene oil, ingot steel and an occasional silk turban for festivals, but will have nothing to do with non-essentials. I wonder what a South Arabian hillsman, clad in his dark indigo fighting kit, would think of young Egypt in bright brown boots and a lounge suit, sipping his "bock" outside a Cairo café, or careering about on a motor-cycle. It is not enough for civilization to create fresh wants and a more complex social system to justify its existence. Well might the militant Moslem say, "Give me the arms and equipment of civilization and Eblis take its luxuries."

Wyman Bury (Abdullah Mansur). Menakha, Yemen. 